\title{
Critical and Higher Order Thinking in Online Threaded Discussions in the Slovak Context
}

\author{
Katarina Pisutova-Gerber and Jana Malovicova \\ Open Society Foundation, Slovakia
}

\begin{abstract}
This article describes and analyzes efforts to use collaborative asynchronous discussion forums in a three semester online education program for NGO leaders and managers in Slovakia. Slovakia, as a country with autocratic styles of teacher-centered education, presents strong barriers to the implementation of collaborative learning activities. The authors used Garrison's four stage cognitive processing categories to analyze some of the online discussions in the program. The two higher order critical thinking categories - integration and solution - appeared in student discussions only when prompted by specific instructional techniques.
\end{abstract}

Keywords: Slovakia; online discussion analysis; authoritarian traditions

\section{Introduction}

Slovakia, similar to other post-communist countries, is struggling with a significantly higher use of authoritarian teaching methods than countries in Western Europe or North America. The individual skills required to compete in and meet the challenges of the $21^{\text {st }}$ century cannot be effectively nurtured in an authoritarian learning environment because such an environment does not promote independent thinking and collaborative and group problem-solving. However, the authoritarian approach to teaching and learning is not unique to Slovakia, nor is it limited to former communist regimes. Traditions in authoritarian teaching exist all over the world (Bates, 2007). By an authoritarian method, the authors refer to a teaching approach that is unilateral in nature, in which students are passive receivers of information from a teacher who holds all the relevant knowledge on the topic of study. An authoritarian approach does not encourage independent thought or self-guidance on the part of students, makes only limited use of discussion in the classroom, does not employ group or collaborative activities, and so on.

In the United States, we see a classic authoritarian style of schooling called the "factory model" (Rogoff, Paradise, Arauz, Correa-Ch’avez, \& Angelillo, 2003), which has been predominant from 
its rise early in the $20^{\text {th }}$ century to the present day. Yet a shift toward a student-focused pedagogy began in the 1960s and now enjoys widening acceptance in the U.S. and across Western education. Cuban (2006) describes the current situation in the United States as a blending of teacher-centered and student-centered practices. Although the teacher-centered approach is still dominant in U.S. schools, many teachers now incorporate an increasing number of studentcentered practices into their teaching routine.

To understand the stagnation in bringing change to pedagogy in Slovakia, an historical perspective is helpful. The cultures of East-Central Europe (a region comprised today of Hungary, Poland, and the Czech and Slovak Republics), have historically been associated with Western European civilization. This occurred about a thousand years ago when the kingdoms in the region accepted Roman Catholic (Western) as opposed to Byzantine (Eastern) Christianity (Szebenyi, 1992). For an entire millennium since that time, these countries were part of a common cultural sphere with the West. For the last few centuries, in particular, under the Hapsburg and Austro-Hungarian empires, they were considered an integral part of Western Europe. However, when totalitarian regimes took over following World War II, the traditional authoritarian teaching style became not only common practice but a rigid paradigm that together with the active suppression of independent thought relegated the region's pedagogy to a political tool for sedating society. In the words of Hannah Arendt: "The aim of totalitarian education has never been to instill conviction, but to destroy capacity to form any" (Arendt, 1968, p.168).

While Western Europe went through student revolts and structural changes in the 1960s and 1970s, and their education systems opened up accordingly, higher education systems in the East were not liberalized (Rozsnyai, 2003). In Poland, Hungary, and Czechoslovakia in particular, education was made widespread and accessible but became centralized, and curricula became heavily politically indoctrinated. The authoritarian approach, which was prevalent in all schools in Europe after WWII, became fixed in place in these countries and experienced little change for over 40 years (Zajda, 2007; Kaser, 2006; Livschiz, 2006).

When political change ultimately came to Central and Eastern Europe in 1989, political pressure on teaching styles diminished. The transformation of the political and economic systems in the region brought the potential for a great shift in the prevailing paradigms in education, research, science, and many other areas. As the turn of events would have it though, a decline in economic production coincided with this transformation and resulted in decreasing investment in many areas, particularly in education, with funding priorities focused more on the social and political transition (Zajda, 2007). Thus, the year 2009 will mark twenty years since the fall of these totalitarian regimes in Europe but with not much having changed in the teaching approach and practices of Slovakia and its neighbors.

In Slovakia, university courses consist of monologue lectures and term exams. In introducing online learning, the focus is often kept on technology. Issues of applying sound and visual media are explored widely, but interaction is often kept between instructor and student, and the authoritarian teaching style is transferred into the online environment without any significant change. 
Yet there are signs of change in the prevailing attitude. The number of teachers and students with international experience is slowly growing. Nejedly (2008) interviewed Slovak university students in an effort to discover the reasons for the low quality of Slovak post-graduate education and got predictable answers from those who compare their international university experience to

the Slovak system. One student with international experience described how common it is in Slovakia to have a professor who reads aloud from textbooks during a lecture. This particular student claimed that he bought a laptop so that he could do his emails during the lecture and keep from falling asleep.

There are also a number of teachers, mostly with international experience, who hold critical viewpoints of the teaching practices at Slovak universities. Teachers with experience from German, British, Dutch, and US universities interviewed by Jarmila Horakova (2008) describe a complete lack of focus on developing critical thinking in students at Slovak universities. Also, Matusova (1997) criticizes Slovak university teachers for simply transferring knowledge. Burjan (2008) notes how an absence of a chance to make any decisions throughout schooling, from primary school throughout university, results in adults who require somebody else to make decisions for them and to tell them what to do. Similar opinions relating to the lack of encouragement of independent thinking and the authoritarian teaching styles at Slovak universities can be found in the work of Zabka and Mojzis (2005) and Mojzis (2008).

\section{Student-Centered Collaborative Approach and Online Collaboration}

The dominant issue in education today is access to information. The amount of accessible information is large and growing rapidly. The problem is how to access it efficiently, how to process it so it makes sense, and how to apply and use the information effectively. Locating reliable information resources is also a top concern. In a knowledge-based society, it is not as important to learn as it is to learn how to learn (Garrison \& Anderson, 2003).

In this sense, students need to be able to think independently, to analyze and evaluate information critically, and to work in teams. There are also authors who argue that collaboration (i.e. the socio-cultural constructivist approach) is necessary to create graduates who are able to compete in a global, knowledge-based society. Since it is not possible for one person to hold all the available knowledge on a topic, there is a need for knowledge to be held in interaction, spread among a learning community (Garvin 1994). Collaboration seems to be an inseparable component of modern teaching and learning. A shift in learning from the familiar face-to-face setting to the online environment brought a few changes and challenges, but the need to focus on collaboration as a means to enable students to think critically and to work together remains.

One of the most frequently used technologies to facilitate collaboration in online settings is an asynchronous discussion forum. Fahy (2001) even called discussions ubiquitous in distance education. Discussions, whether conducted in a face-to-face setting or online, are often an essential part of the course. However, online threaded discussions are in many aspects different from face-to-face discussions (Meyer, 2003). Threaded discussions focus on one speaker at a 
time; they leave a semi-permanent record of discussions; they don't require everybody to participate at the same time; and they enable people to spend as much time as they need to formulate their contributions.

\section{Analysis of Discussion Content}

The written record of online discussion enables teachers and researchers to perform a thorough evaluation and analysis of it. Naturally, a simple counting of posts made by students will not provide any insight into the quality of the discussion. Content analysis of student posts is necessary to discern what level of quality and higher thinking the discussions sustained.

Within the last ten years, a number of frameworks for online discussion content analysis have been developed. In some cases, researchers adopted instruments developed for analysis of faceto-face discussions. For instance, Fahy (2006) adopted the Interaction Process Analysis (IPA), the model developed by Bale in 1950. The IPA model classifies interaction in groups of learners according to its positive and negative socio-emotional content and the amounts of giving or asking for task-related input. Other researchers applied Bloom's taxonomy of educational objectives, developed in 1956 (Meyer, 2004). Bloom's taxonomy defines six categories of student contributions: knowledge, comprehension, application, analysis, synthesis, and evaluation.

There are also a few instruments developed specifically for analysis of online discussion transcripts. For instance, Fahy, Crawford, and Ally (2001) developed Transcript Analysis Tool (TAT) based on Zhu's (1996) analytic model. TAT defines five categories of student contributions: questioning, statements, reflections, scaffolding, and references. Garrison, Anderson, and Archer (2001) developed a model based on critical thinking theory. They proposed a four stage process: (1) triggering (posing the problem), (2) exploration (search for information), (3) integration (construction of possible solution), and (4) resolution (critical assessment of solution).

By using any of the transcript analysis models, it is possible to gain valuable information about critical thinking and cognitive processes present in discussions. However, transcript analysis also raises some problems that need to be addressed. First, ethically, it is necessary to receive consent not only from lecturers but also from students for such an evaluation. Then there are the issues of objectivity and reliability. One may question objectivity when the interpreter's subjective criteria play a role in the process of categorizing and grading messages (Rourke, Anderson, Garrison \& Archer, 2001, Fahy, 2006), and, hence, the reliability of the analysis itself needs to be assessed.

\section{Slovak Online Learning and Use of Collaboration}

Most online learning projects in Slovakia have been focused on technical aspects. Courses are generally offered by technically oriented business companies or technical universities; often, they are automated lectures with self-tests where students work individually and have only occasional contact with the instructor and no contact with co-learners. Some universities have tried to create their e-learning policies and strategies by dealing solely with technical aspects, such as hardware 
and learning management systems. The teaching approach and the pedagogy of the courses rely upon the enthusiasm of the teacher. Hence, there are only a few courses that attempt a truly student-centered collaborative approach.

However, it seems as though most managers expect that implementation of technology will also change the nature and approach to teaching and learning with no further action required (Ozvoldova, 2002). The resulting situation might be best described in the words of Katarina and Hynek Bachraty (2008): “Technologies are new, but students and teachers are the same” (p.197).

Simuth \& Sarmany Schuller (2008) conducted a survey of 274 Slovak students from four different universities, which focused on possible online learning barriers. None of the students indicated that a lack of appropriate technology represents a barrier. Some students, though, complained about a lack of communication with peers. All of the students stated that the most serious barrier was the slow responses from their tutor.

In 2003, evaluative research was conducted on four of the first online courses introduced at Slovak universities. The goal was to identify barriers to the development of online learning that are typical for or unique to Slovakia (Pisutova, 2003). The study identified two online learning barriers caused by authoritarian teaching traditions:

1. Teaching style and teachers' approach to problems. For a long time regimes in Slovakia did not encourage independent thinking. The common pedagogy contained authoritative teaching styles and student memorization of facts. The shift to facilitation roles and collaborative activities represents a change for Slovak teachers. There is a strong tendency to view online learning as only publishing lectures on the Web. Of course, this does not apply to all teachers and universities. There are islands of change growing within the educational arena in Slovakia, most of them initiated as a result of funding from EU programs, USAID, or independent foundations.

2. Issues of independence and responsibility and concepts of collaboration among students. The Slovak higher education system still does not encourage independent thought in students to any significant degree. Therefore, students used to having little more asked of them than memorizing facts will find any other approach to learning to be radical and often uncomfortable. Having teachers as facilitators, students taking responsibility for their own learning, and even asking students to cooperate with their peers are all new concepts in Slovak higher education.

\section{Online Program for NGO Leaders in Slovakia}

The Open Society Foundation, in cooperation with the Centre for Education of Non-profit Organizations (CENO), developed and conducted a three-semester online program for NGO leaders in Slovakia. The first pilot run of the program is now being evaluated. For most instructors and all of the students, this was their first experience with online learning. In order to promote a sense of community for both teachers and students, every semester began and ended 
with a face-to-face meeting. Introductory meetings at the beginning of each semester served to introduce teachers and students to one another and to the coursework and focused on explaining the advantages and principles of peer interactions and group work. Beginning in the second semester, two additional voluntary face-to-face training meetings were added for students who felt that they needed increased personal contact; these additional meetings were designed to ease students' fears, frustration, and confusion related to online participation. The open source learning management system, Moodle, was used because of its cost efficiency but, more importantly, because of its full support for the Slovak language. Also, CENO technical administrators already had experience with this system, which enabled them to handle the technical side of the program and to provide effective technical support for students.

Before beginning preparation of the courses, authors and tutors went through basic training, which was provided by the Slovak Technical University in Bratislava. The authors and tutors gained basic knowledge in online learning and the associated technologies and worked closely with an instructional designer for each course. In the planning stage, the value of collaborative assignments and discussions as learning tools had to be explained numerous times. Even during implementation of the course, though, some aspects of the usefulness of these activities needed to be re-explained and reinforced with the tutors.

In the first semester, students were encouraged to participate in asynchronous discussions, but participation was not obligatory. Questions related to the course topic were posted in a discussion forum each week, and students were encouraged to answer them and analyze the answers. Sixteen students generated 270 messages in 61 threads in this discussion forum. In the second semester, an obligatory discussion assignment was introduced. Students were asked to answer an analytical course topic question and to draw conclusions based on their own practical experience and on course theory. The question was as follows: "Provide an example of a negative experience as a project manager and provide suggestions how to avoid such a situation." They were then asked to react to at least two answers of classmates in a substantive way. In this discussion forum, there were 58 messages in one thread created by 16 students. The general forum in the second semester consisted of 158 messages in 25 threads. In the third semester, two more similar obligatory discussions were used.

On the whole, students evaluated the program as very successful and satisfactory. In fact, 15 out of 16 students admitted into the first semester completed all three semesters successfully, which is an unusually strong course retention rate, especially given the fact that this was their first online course. The students were happy with the technical support provided as well as with the response time and supportive conduct of their tutors.

\section{Methodology}

Data for evaluation of the courses were gathered from observations of online interactions of students with tutors and among students during the course as well as from questionnaires given to students at the end of each semester and interviews with tutors and students at the end of the full program. In order to understand the thinking processes and to be able to determine how our 
threaded discussions worked, we decided to use Garrison's (2001) Critical Thinking Categories (CTC) model. We analyzed general discussion in the first and second semester and then conducted a separate analysis of obligatory discussion in the second semester.

For the analysis, we placed each contribution into one of four categories as defined by Garrison: (1) triggering (posing the problem); (2) exploration (search for information); (3) integration (construction of possible solution); and (4) resolution (critical assessment of solution). Further examples of these categories, their indicators, and the socio-cognitive processes captured by the indicators, are presented in Table 1, taken in total from Garrison et al.

\section{Table 1}

Categories of Contributions (Based on Garrison et al.)

\begin{tabular}{|c|c|c|}
\hline Category & Indicators & Socio-cognitive Processes \\
\hline Triggering & $\begin{array}{l}\text { Recognizing the problem } \\
\text { Sense of puzzlement }\end{array}$ & $\begin{array}{l}\text { Presenting background information that } \\
\text { culminates in a question } \\
\text { Asking questions } \\
\text { Messages that take discussion in a } \\
\text { different direction }\end{array}$ \\
\hline Exploration & $\begin{array}{l}\text { Divergence within online } \\
\text { community } \\
\text { Divergence within single } \\
\text { message } \\
\text { Information exchange } \\
\text { Suggestions for consideration } \\
\text { Brainstorming } \\
\text { Leaps to conclusions }\end{array}$ & $\begin{array}{l}\text { Unsubstantiated contradiction of } \\
\text { previous ideas } \\
\text { Many different ideas/themes presented } \\
\text { in one message } \\
\text { Personal narratives/descriptions/facts } \\
\text { (not used as evidence) } \\
\text { Author explicitly characterizes message } \\
\text { as exploration-e.g. Does that seem right? } \\
\text { Adds to established points, but does not } \\
\text { systematically defend/justify/develop } \\
\text { Offers unsupported opinions }\end{array}$ \\
\hline Integration & $\begin{array}{l}\text { Convergence among group } \\
\text { members } \\
\text { Convergence within a single } \\
\text { message } \\
\text { Connecting ideas, synthesis } \\
\text { Creating solutions }\end{array}$ & $\begin{array}{l}\text { Reference to previous message followed } \\
\text { by substantiated agreement, e.g. I agree } \\
\text { because... } \\
\text { Building on, adding to other's ideas } \\
\text { Justified, developed, defensive, yet } \\
\text { tentative hypotheses } \\
\text { Integrating information from various } \\
\text { sources: textbook, articles, personal } \\
\text { experience } \\
\text { Explicit characterization of message as a } \\
\text { solution }\end{array}$ \\
\hline Solution & Vicarious application to real & \\
\hline
\end{tabular}




\begin{tabular}{|l|l|l|}
\hline & $\begin{array}{l}\text { world } \\
\text { Testing solutions } \\
\text { Defending solutions }\end{array}$ & \\
\hline
\end{tabular}

SOURCE: Garrison et al. (2001), p. 15-16.

We also used, in a similar way to Garrison et al. and later Meyer (2003), a fifth category for contributions that did not fit into any of the previous categories and included social and other posts unrelated to the course content. The unit of analysis was the complete posting of the student, as in Garrison (2001). However, given the length and complexity of some student postings, this was problematic. The issue was resolved by assessing the contribution's main, or predominant, quality, which introduced a subjective aspect to the analysis.

In order to eliminate at least some of the subjectivity, both authors made categorizations of postings independently. It was discovered that $84 \%$ of messages were in categories labeled identically by both authors. Since our total number of messages was not extremely high (270 in general discussion in the first semester, 158 for the second semester, and 58 for the obligatory discussion in the second semester), we were able to discuss the categorizing of the remaining $16 \%$ of messages and decide on their category placements together.

\section{Results}

In order to illustrate our point, we present here results and analysis of discussions for only the first and the second semesters. Analysis of discussions in the third semester shows results very similar to discussions in the second semester. Table 2 shows the percentage of messages in each of the five categories used for the three discussion forums analyzed.

\section{Table 2}

Categorizing of Discussions

\begin{tabular}{|c|c|c|c|}
\hline Category & $\begin{array}{c}\text { General Discussion } \\
\text { Semester 1 }\end{array}$ & $\begin{array}{c}\text { General Discussion } \\
\text { Semester 2 }\end{array}$ & $\begin{array}{c}\text { Obligatory Discussion } \\
\text { Semester 2 }\end{array}$ \\
\hline Triggering & $11.5 \%$ & $13 \%$ & $3.4 \%$ \\
\hline Exploration & $20.8 \%$ & $27.5 \%$ & $36.2 \%$ \\
\hline Integration & $0 \%$ & $0 \%$ & $37.9 \%$ \\
\hline Solution & $0 \%$ & $0 \%$ & $20.7 \%$ \\
\hline Other & $67.7 \%$ & $59.5 \%$ & $1.8 \%$ \\
\hline
\end{tabular}

Clearly, general discussion forums were used mostly for resolving administrative and technical problems, and the part of the discussion that dealt with course content did not include any higherlevel thinking. Students were primarily summarizing problems and exploring options. However, when not obliged to do so as part of an assignment, they made no effort to solve any of the proposed problems. 
Of further interest is the evaluation feedback that students provided about the obligatory discussion activity in the second semester. Most of them acknowledged that having the opportunity to read the opinions of others and to learn about their experiences was very useful. Some of the views are presented below:

"It was a very positive experience. It gave me very useful information and insight on problems other NGOs face."

"I liked to know opinions and experiences of people who are in the field longer than me."

"I enjoyed the discussion very much. It was free-flowing, it had variety and it gave me new information."

But they also complained that when it was obligatory for them to form and present opinions on specific issues, it required too much time and effort:

"I did not like the fact that it was compulsory. I would happily participate in a voluntary discussion, this irritated me."

"I did not feel comfortable to be asked to express my opinion. It was really hard for me."

"It required lot of my time to read all the reactions in order to choose which one I want to respond to."

"I felt like being treated like a little child - being told to participate in a discussion. Discussion should be an easy and relaxing activity people do for fun. Here we were guided to do it and forced to spend all that time reading and composing thoughts."

Teachers generally did not see much profit for themselves in using obligatory discussions in the course.

"Reading and evaluating for marking all these posts was way more time-consuming than I would ever suspect it to be."

"What did you say before that discussion activities were good for?"

\section{Analysis}

We compared the analysis of the obligatory discussion from the second semester with results of Garrison et al. (2001) and Meyer (2003, 2004), who used CTC according to the Garrison method to analyze threaded discussions in courses at the University of Dakota. The comparison is shown in Table 3. 
Table 3

Comparison of Results

\begin{tabular}{|c|c|c|c|c|}
\hline Category & $\begin{array}{c}\text { Obligatory } \\
\text { Discussion } \\
\text { Semester 2 }\end{array}$ & $\begin{array}{c}\text { Distributions in } \\
\text { Garrison and } \\
\text { Colleagues } \\
(2001)\end{array}$ & $\begin{array}{c}\text { Distribution in } \\
\text { Meyer (2003) }\end{array}$ & $\begin{array}{c}\text { Distribution in } \\
\text { Meyer (2004) }\end{array}$ \\
\hline Triggering & $3.4 \%$ & $8 \%$ & $18.18 \%$ & $18.4 \%$ \\
\hline Exploration & $36.2 \%$ & $42 \%$ & $50.59 \%$ & $27.0 \%$ \\
\hline Integration & $37.9 \%$ & $13 \%$ & $22.24 \%$ & $32.4 \%$ \\
\hline Solution & $20.7 \%$ & $4 \%$ & $6.66 \%$ & $19.8 \%$ \\
\hline Other & $1.8 \%$ & $33 \%$ & $3.33 \%$ & $2.5 \%$ \\
\hline
\end{tabular}

Both Garrison and Meyer analyzed messages in general forums of online courses, where students were discussing various issues throughout the duration of the course. In our case, we analyzed only discussion related to one specific assignment.

We assume that the low number of posts in the 'triggering' category is caused by the fact that in our case the questions were posted as part of an assignment. In most cases, students gravitated toward trying to explore, integrate, and find solutions. By being asked to find answers, they were also pushed into trying to find a solution; hence, our percentage of 'solution' category posts is higher than in the discussions analyzed by Garrison or Meyer. However, it is clear that even in the context of Slovak authoritarian traditions, it is possible to achieve higher order thinking, integration, and solution searching in asynchronous discussions by applying encouraging instructional techniques.

Biesenbach-Lucas (2004) says that instructors must design the use of technologies and the learning environment to encourage collaborative work. Edelstein and Edwards (2002) compare course design and discussion facilitation to the work of an architect: "Just as the architect will design a blueprint to provide the homebuilder direction in completing the house, the facilitator must design and manage the threaded discussion to direct students in achieving the intended learning outcomes" (Introduction section, para. 2). Edelstein and Edwards also consider active and focused participation in discussions to be an expectation of most online courses. However, in the first semester in our case, although students were told that they were expected to participate regularly and substantially, the discussion showed no signs of higher order thinking.

Palloff and Pratt (2003) provide instructions on how to plan and create asynchronous discussions for young students participating in their first online course. They suggest the following:

- To create specific posting times, for example, the first response to a discussion question is due online by Wednesday,

- To be specific about the minimum number of responses to other student's posts required for particular discussion, 
- To be specific about what constitutes a substantive post. A post is considered a substantive contribution to the discussion wherein a student either comments on other posts or begins a new topic. Posts like "good job", "I agree" or "I like the way you think" are important for the community building process, but students must be instructed that these are not considered substantive posts. (p.8)

This was the basic approach we used when planning the obligatory discussion task during the second semester. From the reactions of students, we could see that although they did not like being directed and they did not like that this particular discussion required increased effort, they were able to appreciate its learning value. Still, it is difficult to prompt students to participate in discussion and put effort into thinking and designing solutions without making them feel that they are being directed.

\section{Conclusions and Recommendations}

Problems arising from a rigid authoritarian approach to education throughout the second half of the $20^{\text {th }}$ century are being experienced by countries all across the post-communist region. For instance, Soukalova (2002) describes similar problems in the Czech Republic and Rozsnay (2003) does the same for the region of Hungary, Czech Republic, and Poland. From our study we can draw conclusions and recommendations on three levels: recommendations for course design, recommendations for institutional management, and recommendations for more research.

Concerning course design, there are three implications:

1. Before starting design work on a course, it is important to work closely with the authors and tutors. If teachers don't understand and respect the values of collaborative methods, it is unlikely that they will apply them so that students participate and gain valuable experience. In our case, due to time and funding constraints, the training of tutors was brief, and it did not include an opportunity for them to experience and appreciate online collaborative activities as a learning tool. This hampered the use of collaborative methods during the planning period and the involvement and encouragement of tutors during discussions.

2. It is important to work with students' expectations. We were able to make students understand that the course would not be "easier" because it is online. However, we failed to explain at the beginning of the course the purpose, importance, and learning value of discussions. It is necessary to ensure that students do not expect a discussion forum to be easy and relaxing.

3. Students in Slovakia do not have a great deal of experience with collaborative activities and discussions. So if these activities are to be used in an online course, students need to be introduced to these methods. Instructors cannot expect students to participate enthusiastically and voluntarily in something that is so new and unfamiliar to them. Assignments consisting of discussions should be made obligatory in this environment, 
even if course participants are older adults. However, it is important to formulate instructions carefully so that students don't find the environment to be patronizing.

Additionally, there is a clear implication for universities or NGOs that are creating their own elearning strategies.

If e-learning is to be accepted as a new and effective form of pedagogy then it is necessary from the outset to change teachers' approaches to and perceptions of collaborative learning. E-learning policy needs to address not only technical but also methodological teacher preparation.

Due to the lack of funding and attention from education policymakers and university administrators, the online learning sector in the region of Central and Eastern Europe began its growth slightly later, and it proceeded more slowly than in Western Europe and North America. As well, thanks to authoritarian teaching traditions in the region, the number of online courses using collaborative approaches remains limited. This means also that the number of evaluative research studies on online courses that introduce the collaborative approach is low.

In order to formulate proper recommendations for strategies for training and student support, similar additional studies in the region should be conducted. 


\section{References}

Arendt, H. (1968). Totalitarianism. New York: Harcourt Brace Jovanovich

Bachraty, H., \& Bachrata, K. (2008). Mathematical distance education and e-Learning. Proceedings of the ICETA Conference, 2008, Kosice, Slovakia: Elfa, s.r.o., 197-200

Bates, T (2007, May). Technology as a force for change. Paper presented at SCBEWC International Conference, Beijing, China.

Biesenbach-Lucas, S. (2004). Asynchronous web discussions in teacher training courses: Promoting collaborative learning-or not? AACE Journal, 12(2), 155-170.

Burjan, V. (2008, October 13) Rodičia, učte svoje deti rozhodovat'sa! Školy to nerobia. (Parents, teach your children to make decisions. Schools are not doing it). Message posted to http://burjan.blog.sme.sk/c/167545/Rodicia-ucte-svoje-deti-rozhodovat-sa-Skoly-tonerobia.html

Cuban, L. (2006). Getting past futile pedagogical wars. Phi Delta Kappan, June 2006, 793-795.

Edelstein, S., and Edwards, J. (2002). If you build it, they will come: Building learning communities through threaded discussions. The Online Journal of Distance Learning Administration 5(1). Retrieved, April 12, 2008, from http://www.westga.edu/ distance/ojdla/spring51/edelstein51.html

Fahy, P.J. (2001). Addressing some common problems in Transcript Analysis. The International Review of Research in Open and Distance Learning 1(2). Retrieved April 1, 2008, from http://www.irrodl.org/index.php/irrodl/article/view/321/530

Fahy, P.J., Crawford, G., Ally, M. (2001). Patterns of interaction in a computer conference transcript. The International Review of Research in Open and Distance Learning 2(1).

Fahy, P.J. (2005). Online and face-to-face group interaction processes compared Using Bales' Interaction Process Analysis (IPA. European Journal of Open, Distance and E-Learning. Retrieved April 2, 2008, from http://www.eurodl.org/materials/contrib/2006/Patrick_J_Fahy.htm

Garrison, D. R., Anderson, T., and Archer, W. (2001). Critical thinking, cognitive presence, and computer conferencing in distance education. The American Journal of Distance Education, 15(1), 7-23.

Garrison, D.R. \& Anderson, T. (2003). E-Learning in the $21^{\text {st }}$ Century. A framework for research and practice. London: RoutlegeFalmer.

Garvin, D.A. (1994). Building a learning organization. Business Credit, 96(1), 19-28.

Horakova, J. (2008) V com su zahranicne univerzity lepsie? (What are foreign universities better in?) SME. Retrieved, January 5, 2008, from: http://www.sme.sk/c/3661043/V-com-suzahranicne-univerzity-lepsie.html 
Kaser, M. (2006). Resources for Russian education: Soviet strategies in historical context. History of Education, 35(4-5), 561-583.

Livschiz, A. (2006). Pre-revolutionary in form, Soviet in content? Wartime educational reforms and the postwar quest for normality. History of Education, 35(4-5), 541-560.

Matusova, S. (1997). Democratic values as a challenge for education. European Education, 29(3), 65-77

Meyer, K.A. (2003). Face-to-face versus threaded Discussions: The role of time and higher-order thinking. Journal for Asynchronous Learning Networks, 7(3), 55-65. Retrieved March 22, 2008, from http://www.sloanc.org/publications/jaln/v7n3/pdf/v7n3_meyer

Meyer, K.A. (2004). Evaluating online discussions. Four different frames of analysis. Journal for Asynchronous Learning Networks, 8(2), 101-114. Retrieved March 20, 2008, from http://www.sloan-c.org/publications/jaln/v8n2/pdf/v8n2 meyer

Nejedly T. (2008). Elitne vysoke skoly? Studentom staci titul. (Elitarian universities? For students degree is enough). Hospodarske noviny. Retrieved on October 19, 2008, from http://www.governance.sk.

Ozvoldova, M. (2002). Je e-learning perspektivne vzdelavanie na Slovensku? - Is e-Learning perspective form of education in Slovakia? In E-LEARN, 2002 - Proceedings of the Conference, Zilina, Slovakia: University of Zilina, 10-17.

Palloff, R.M. \& Pratt, K. (2003). The virtual student. A profile and guide to working with online learners. San Francisco, CA: Jossey-Bass.

Pisutova, K. (2003) Online learning in Slovakia: Titanic or Noah's Ark? Unpublished master's thesis, University of British Columbia, Vancouver, Canada.

Rogoff, B., Paradise,R., Arauz, R. M.. Correa-Ch’avez, M., \& Angelillo C. (2003). Firsthand learning through Internet participation. Annual Review Psychology, 54, 175-203.

Rourke, L., Anderson, T., Garrison, D. R., \& Archer, W. (2001). Methodological issues in the content analysis of computer conference transcripts. International Journal of Artificial Intelligence in Education, 12, 8-22. Retrieved December 14, 2007, from http://aied.inf.ed.ac.uk/members01/archive/vol_12/rourke/full.html

Rozsnyai, C. (2003). Quality assurance before and after 'Bologna' in the Central and Eastern Region of the European Higher Education Area with a focus on Hungary, the Czech Republic and Poland. European Journal of Education, 38(3), 2003.

Simuth, J. \& Sarmany Schuller, I. (2008) Motivacne kognitivno stylove factory v online vzdelavani (Motivational cognitive style factors in online learning). Proceedings of eLearn Conference, February 200, Zilina, Slovakia: University of Zilina, 134-137.

Soukalova, A. (2002). Czech higher education - disaster in progress. The Word We Live In, Summer, 35-37. 
Szebenyi, P. (1992). Change in the systems of public education in East Central Europe. Comparative Education, 28(1), 19-32.

Zabka, J., Mojzis M., (2005, May 5). Skola a tvorivost (School and creativity). Tyzden. 20. Retrieved February 5, 2009 from http://www.tyzden.sk/old_archiv.php?w=art\&idart=2673\&idiss=57

Zajda, J. (2007). Guest editor's introduction. European Education, 39(2), 3-19.

Zhu, E. (1996). Meaning negotiation, knowledge construction, and mentoring in a distance learning course. In Proceedings of Selected Research and Development Presentations at the 1996 National Convention of the Association for Educational Communications and Technology. Indianapolis, IN. (ERIC Document Reproduction Service No. ED 397 849)

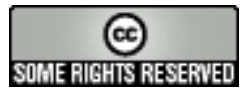

